\title{
Analisis Kesalahan Siswa Dalam Menyelesaikan Soal Barisan dan Deret Aritmatika Menggunakan Tahapan Kesalahan Newman
}

\author{
Refli Annisa ${ }^{1}$, Kartini Kartini ${ }^{2}$ \\ 1,2 Program Studi Pascasarjana Pendidikan Matematika, Fakultas Keguruan dan Ilmu Pendidikan, Universitas Riau, \\ Kampus Bina Widya Km 12,5 Simpang Baru, Pekanbaru, Indonesia \\ Email penulis pertama: refli.annisa@gmail.com
}

\begin{abstract}
The purpose of this study was to analyze student errors in solving arithmetic sequences and series problems. This research needs to be done so that it can help find any mistakes made by students so that it will be easier to find solutions to minimize the occurrence of these errors in learning. The subjects of this study were 23 students of class XI at SMAN 1 Hulu Kuantan. The analysis was carried out by giving a written test in the form of description questions, amounting to 5 questions. The research was conducted in the odd semester of the 2020/2021 school year. In this study, using the error analysis stage according to Newman. Data analysis refers to Miles and Huberman's model which consists of data reduction, data presentation, and conclusion drawing. Based on the data analysis, the percentage of reading error is $13 \%$, comprehension error is $22 \%$, transformation error is 35\%, process skill error is $44 \%$, and encoding error is $9 \%$.
\end{abstract}

Keywords: Error Analysis, Arithmetic sequences and sequences, Qualitative Descriptive, High school student

\begin{abstract}
Abstrak
Tujuan penelitian ini adalah untuk menganalisis kesalahan siswa dalam menyelesaikan soal barisan dan deret aritmatika. Penelitian ini perlu dilakukan agar bisa membantu menemukan kesalahan apa saja yang dilakukan siswa sehingga akan lebih mudah menemukan solusi untuk meminimalisir terjadinya kesalahan tersebut dalam pembelajaran. Subjek penelitian ini adalah 23 orang siswa kelas XI di SMAN 1 Hulu Kuantan. Analisis dilakukan dengan memberikan tes tertulis berbentuk soal uraian yang berjumlah 5 soal. Penelitian dilakukan pada semester ganjil tahun ajaran 2020/2021. Dalam penelitian ini menggunakan tahapan analisis kesalahan menurut Newman. Analisis data mengacu pada model Miles dan Huberman yang terdiri dari reduksi data, penyajian data, dan penarikan kesimpulan. Berdasarkan analisis data diperoleh persentase kesalahan reading error $13 \%$, comprehension error $22 \%$, transformation error $35 \%$, process skill error $44 \%$, dan encoding error $9 \%$.
\end{abstract}

Kata kunci: Analisis Kesalahan, Barisan dan deret aritmetika, Deskriptif Kualitatif, Siswa SMA

Copyright (c) 2021 Refli Annisa, Kartini

$\triangle$ Corresponding author: Kartini

Email Address: kartini@lecturer.unri.ac.id (Kampus Bina Widya Km 12,5 Simpang Baru, Pekanbaru, Indonesia) Received 10 Desember 2020, Accepted 15 Maret 2021, Published 16 Maret 2021

\section{PENDAHULUAN}

Matematika seringkali dianggap pelajaran yang sulit dipahami bagi sebagian siswa. Salah satu penyebabnya karena matematika itu berhubungan dengan angka, rumus, dan berhitung. Padahal matematika memiliki banyak manfaat dalam kehidupan. (Ratnasari et al., 2017) mengungkapkan pelajaran matematika berfungsi untuk membentuk pola pikir anak. Matematika juga berkaitan dengan kemajuan teknologi sehingga siswa harusnya bisa menguasai pelajaran matematika. Menurut (Budhi et al., 2015) tujuan utama mempelajari matematika adalah untuk dapat menemukan solusi dari suatu masalah atau soal. Konsep-konsep pada matematika selalu berkaitan satu sama lain. Lebih lanjut, (Ristanty et al., 2017) mengatakan jika siswa telah memahami konsep terlebih dahulu, maka akan mudah baginya untuk menerima materi selanjutnya serta mampu menyelesaikan suatu masalah yang diberikan kepada mereka.

Namun, pada saat ini siswa menunjukkan secara keseluruhan belum mampu mengembangkan 
daya nalarnya dalam proses pembelajaran matematika (Murtikusuma, 2015). Sejalan dengan yang dikatakan (Karnasih, 2015) bahwa sepanjang proses penyelesaian masalah berlangsung, seringkali siswa membuat kecerobohan, serta ada beberapa siswa yang memberikan jawaban yang salah. Sebagaimana dikatakan (Siregar, 2017) bahwa matematika merupakan pelajaran yang sampai ini oleh para siswa masih dianggap sulit. Oleh karena itu guru hendaknya membantu siswa dalam menghadapi kesulitan tersebut. Namun, guru hendaknya menganalisis terlebih dahulu apa saja kesalahan yang dilakukan oleh siswa. Lebih lanjut (Setiawan et al., 2018) mengatakan bahwa analisis kesalahan adalah suatu penyelidikan terhadap kesalahan atau ketidaksesuaian terhadap sesuatu hal yang benar atau prosedur yang telah ditetapkan sebelum nya yang bersifat sistematis, konsisten, maupun insidental untuk mengetahui kekeliruan atau kesalahannya.

Salah satu materi yang diajarkan di SMA kelas XI pada pelajaran matematika adalah barisan dan deret aritmatika. Barisan dan deret aritmatika merupakan salah satu materi yang banyak digunakan dalam kehidupan sehari-hari. Contohnya saja kita bisa menggunakan barisan dan deret aritmatika dalam menghitung besar tabungan dalam beberapa tahun jika kita menabung disuatu bank dengan selisih kenaikan nominal yang ditabung setiap bulannya tetap. Oleh karena itu sangat penting bagi siswa untuk memahami dan menguasai materi barisan dan deret aritmatika tersebut.

Kenyataan di lapangan masih banyak siswa yang mengalami kesulitan menyelesaikan soal barisan dan deret aritmatika. Seperti yang diungkapkan oleh (Septiahani et al., 2020) yang hasil penelitiannya menunjukkan bahwa dalam mengerjakan soal barisan dan deret SMK masih tergolong rendah. Oleh karena itu perlu ditinjau lebih dalam kesalahan apa saja yang dilakukan siswa tersebut. Penelitian yang fokus pada diagnosis kesalahan bukanlah suatu hal yang baru (Ekayanti, 2017), telah ada beberapa penelitian dengan topik yang serupa, seperti (Nur et al., 2018) yang telah melakukan penelitian tentang analisis kesalahan siswa pada soal cerita materi barisan dan deret aritmatika dimana hasil penelitiannya menunjukkan penyebab kesalahan yang dilakukan siswa dalam menyelesaikan soal materi barisan dan deret aritmatika yaitu kurangnya pemahaman siswa terhadap simbol dan rumus pada barisan dan deret aritmatika. Kesalahan juga terjadi dikarenakan siswa kurangnya ketelitian siswa dalam mengerjakan soal dan siswa tidak terbiasa melakukan pengoreksian jawaban serta menuliskan kesimpulan akhir. Begitu pula dengan penelitian yang dilakukan oleh (Handayani et al., 2020) dimana hasilnya menunjukkan jenis kesalahan yang siswa lakukan dalam menyelesaikan soal cerita materi barisan dan deret aritmatika yaitu kesalahan konsep, kesalahan menggunakan data, kesalahan interpretasi bahasa, kesalahan teknis, dan kesalahan penarikan kesimpulan.

Berdasarkan permasalahan tersebut, peneliti merasa perlu dilakukan penelitian untuk menganalisis kesalahan siswa dalam menyelesaikan soal barisan dan deret aritmatika. Dalam penelitian ini akan dilakukan analisis kesalahan dengan menggunakan tahapan analisis menurut Newman. (Suyitno \& Suyitno, 2015) mengungkapkan prosedur Newman bisa digunakan untuk menentukan jenis kesalahan siswa dalam melakukan masalah matematika. Tahapan analisis kesalahan menurut Newman terdiri dari lima tahapan, yaitu kesalahan membaca soal (reading error), kesalahan 
memahami masalah (comprehension error), kesalahan transformasi masalah (transformation error), kesalahan keterampilan proses (process skill error), dan kesalahan penulisan jawaban (encoding error) (Sunardiningsih et al., 2019).

Tujuan dari penelitian ini adalah untuk mengetahui seberapa besar persentase kesalahan siswa menyelesaikan soal metematika materi barisan dan deret aritmatika berdasarkan analisis Newman di kelas XI SMAN 1 Hulu Kuantan. yang terdiri dari beberapa jenis kesalahan yaitu (1) kesalahan membaca soal, (2) kesalahan memahami masalah, (3) kesalahan transformasi, (4) kesalahan ketrampilan proses, dan (5) kesalahan penulisan jawaban.

\section{METODE}

Penelitian ini merupakan penelitian deskriptif kualitatif untuk meneliti kesalahan yang dilakukan siswa dalam menyelesaikan soal materi barisan dan deret aritmatika. Subjek penelitian ini adalah 23 orang siswa kelas XI SMAN 1 Hulu Kuantan. Analisis kesalahan yang digunakan dalam penelitian ini menggunakan tahapan analisis kesalahan menurut Newman. Dalam mengidentifikasi kesalahan-kesalahan yang dilakukan oleh siswa dilakukan dengan melihat langkah-langkah penyelesaian yang dibuat siswa dalam menyelesaikan tes yang diberikan. Maka dari itu, dibutuhkan indikator-indikator yang digunakan untuk mempermudah indentifikasi kesalahan yang dilakukan siswa. Indikator-indikator kesalahan yang peneliti buat sesuai dengan analisis Newman. Indikatorindikator tersebut disajikan dalam Tabel 1.

Tabel 1. Indikator Kesalahan

\begin{tabular}{|l|l|}
\hline Jenis-Jenis Kesalahan & Indikator Kesalahan \\
\hline reading error & Siswa salah dalam membaca soal \\
\hline comprehension error & $\begin{array}{l}\text { Siswa tidak memahami informasi apa saja yang ada pada } \\
\text { soal dengan lengkap. } \\
\text { Salah dalam menentukan apa yang diketahui dari soal }\end{array}$ \\
\hline transformation error & $\begin{array}{l}\text { Salah menentukan rumus yang digunakan dalam langkah- } \\
\text { langkah penyelesaian soal }\end{array}$ \\
\hline process skill error & $\begin{array}{l}\text { Salah dalam mengoperasikan perhitungan dalam } \\
\text { menyelesaikan soal }\end{array}$ \\
\hline encoding error & $\begin{array}{l}\text { Salah dalam menentukan jawaban akhir ataupun tidak } \\
\text { menentukan jawaban akhir dari soal }\end{array}$ \\
\hline
\end{tabular}

Modifikasi dari (Fatahillah et al., 2017)

Alat pengumpulan data dalam penelitian ini adalah tes tertulis yang terdiri dari 5 soal. Peneliti memberikan tes tentang barisan dan deret aritmatika kepada 23 siswa kelas XI SMAN 1 Hulu Kuantan. Penelitian dilakukan pada semester ganjil tahun ajaran 2020/2021. Sebelum soal digunakan, terlebih dahulu peneliti uji cobakan soal tersebut dikelas yang tidak termasuk sebagai subjek penelitian. Hal ini bertujuan untuk mengetahui apakah instrumen yang digunakan nanti memenuhi kriteria layak untuk digunakan atau tidak. Perhitungan yang dilakukan adalah perhitungan validitas, reliabilitas, daya pembeda, dan tingkat kesukaran soal. Berikut adalah rekapitulasi dari hasil perhitungan uji validitas, reliabilitas, daya pembeda, dan tingkat kesukaran dari uji coba soal dapat 
dilihat pada Tabel 2.

Tabel 2. Rekapitulasi Hasil Uji Coba Soal

\begin{tabular}{|c|c|c|c|c|c|}
\hline $\begin{array}{l}\text { No. Butir } \\
\text { Soal }\end{array}$ & Validitas & Reliabilitas & $\begin{array}{l}\text { Daya } \\
\text { Beda }\end{array}$ & $\begin{array}{l}\text { Tingkat } \\
\text { Kesukaran }\end{array}$ & Keterangan \\
\hline 1 & Valid & \multirow{5}{*}{ Tinggi } & Cukup & Mudah & digunakan \\
\hline 2 & Valid & & Cukup & Sedang & digunakan \\
\hline 3 & Valid & & Cukup & Sedang & digunakan \\
\hline 4 & Valid & & Cukup & Sedang & digunakan \\
\hline 5 & Valid & & Cukup & Sukar & digunakan \\
\hline
\end{tabular}

Berdasarkan hasil rekapitulasi pada Tabel 2 dapat disimpulkan bahwa soal layak digunakan untuk penelitian. Berikut adalah bentuk soal instrumen tes yang digunakan dalam penelitian ini.

Tabel 3. Soal yang Digunakan

\begin{tabular}{|c|l|}
\hline Nomor Soal & \multicolumn{1}{|c|}{ Soal } \\
\hline 1 & $\begin{array}{l}\text { Manakah barisan berikut ini yang termasuk barisan aritmatika dan yang tidak } \\
\text { termasuk barisan aritmatika? Berikan alasannya! } \\
\end{array}$ \\
& $\begin{array}{l}\text { a. } 3,-1,-5,-9,-13,-17, \ldots \\
\text { b. } \frac{1}{2}, \frac{3}{4}, 1, \frac{5}{4}, \frac{3}{2}, \frac{7}{4}, \ldots \\
\text { c. } 2,4,6,8,12,14, \ldots\end{array}$ \\
\hline 2 & Tentukan suku ke 35 dari barisan $5,7,9,11, \ldots !$ \\
\hline 3 & Jika $\mathrm{U}_{\mathrm{n}}=3 \mathrm{n}-7$ merupakan barisan aritmatika, hitunglah bedanya! \\
\hline 4 & $\begin{array}{l}\text { Dari suatu deret aritmatika diketahui } \mathrm{U}_{2}=10 \text { dan } \mathrm{U}_{6}=26 . \text { Hitunglah jumlah } 22 \\
\text { suku pertama! }\end{array}$ \\
\hline 5 & $\begin{array}{l}\text { Sebuah tali dibagi menjadi } 10 \text { bagian yang panjangnya masing-masing } \\
\text { membentuk deret aritmatika, apabila yang paling pendek panjangnya } 5 \text { cm dan } \\
\text { yang paling panjang adalah 41 cm, hitunglah panjang tali semula! }\end{array}$ \\
\hline
\end{tabular}

\section{HASIL DAN DISKUSI}

Peneliti melakukan analisis jawaban siswa setelah soal diberikan untuk mengetahui kesalahan apa saja yang dilakukan siswa dengan analisis kesalahan Newman. Berdasarkan hasil perhitungan yang telah dilakukan, diperoleh rata-rata persentase tiap aspek kesalahan yang dilakukan siswa berdasarkan banyak siswa yang melakukan kesalahan, yaitu:

Tabel 4. Persentase Kesalahan Siswa Menurut Analisis Kesalahan Newman

\begin{tabular}{|c|c|c|c|c|c|c|}
\hline \multirow[t]{2}{*}{ Jenis-Jenis Kesalahan } & \multicolumn{5}{|c|}{ Banyak Siswa } & \multirow{2}{*}{$\begin{array}{l}\text { Persentase } \\
\text { Kesalahan }\end{array}$} \\
\hline & Soal 1 & Soal 2 & Soal 3 & Soal 4 & Soal 5 & \\
\hline reading error & 0 & 0 & 2 & 1 & 0 & $13 \%$ \\
\hline comprehension error & 3 & 1 & 0 & 0 & 1 & $22 \%$ \\
\hline transformation error & 0 & 1 & 1 & 3 & 3 & $35 \%$ \\
\hline process skill error & 0 & 2 & 1 & 3 & 4 & $44 \%$ \\
\hline encoding error & 0 & 0 & 0 & 1 & 1 & $9 \%$ \\
\hline
\end{tabular}

Berdasarkan Tabel 4 terlihat bahwa kesalahan yang paling banyak dilakukan siswa adalah pada jenis kesalahan process skill error. Untuk lebih jelasnya akan dijabarkan analisis kesalahan yang 
dilakukan siswa pada tiap item soal. Subjek yang dipilih sebagai informan dalam penelitian ini yaitu DD, AS, DS, NN dan SP. Berikut hasil analisis menurut kategori Newman.

\section{Reading Error (Kesalahan Membaca Soal)}

Berikut adalah persentase kesalahan pada reading eror untuk setiap soal.

Tabel 5. Persentase Kesalahan Reading Eror

\begin{tabular}{|c|c|}
\hline Nomor Soal & Persentase \\
\hline 1 & $0 \%$ \\
\hline 2 & $0 \%$ \\
\hline 3 & $8.7 \%$ \\
\hline 4 & $4.4 \%$ \\
\hline 5 & 0 \\
\hline
\end{tabular}

Tabel 5 memperlihatkan bahwa kesalahan reading error yang dilakukan siswa terdapat pada soal nomor 3 dan 4. Pada Gambar 1 diberikan salah satu contoh kesalahan reading error yang dilakukan siswa DD.

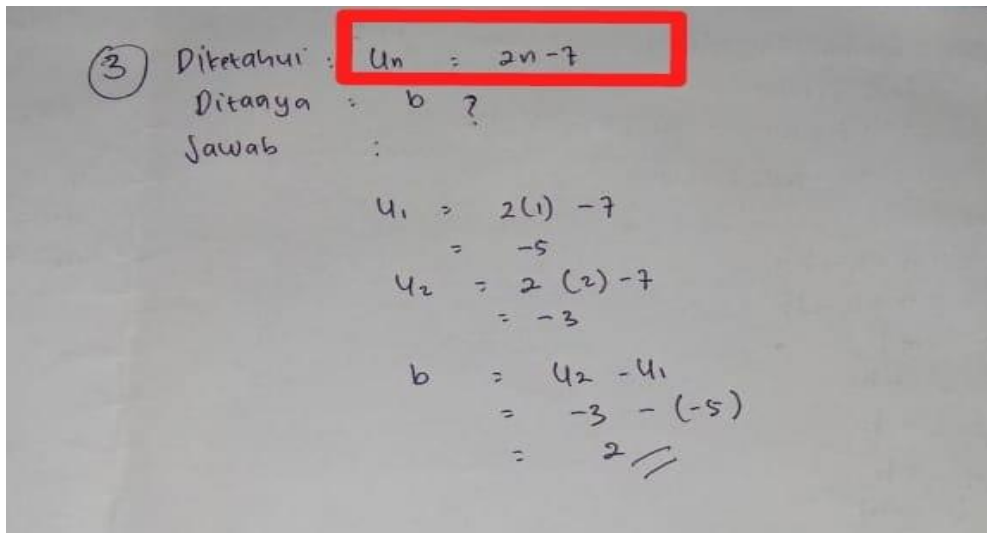

Gambar 1. Jawaban siswa soal nomor 3

Berdasarkan Gambar 1 terlihat jelas bahwa DD salah membaca rumus suku yang diberikan, yaitu seharusnya $U_{n}=3 n-7$ tapi dirubah menjadi $U_{n}=2 n-7$. Hal ini karena siswa kurang teliti dalam membaca soal. Hal ini sesuai dengan penelitian yang dilakukan oleh (D. Rahmawati \& Permata, 2018) yang mengungkapkan bahwa pada kesalahan membaca siswa masih mengalami kesalahan dalam memaknai kalimat dengan tepat, kesalahan dalam menemukan kata kunci pada soal dan kesalahan membaca informasi serta simbol matematika dalam soal dengan lengkap. Hal ini juga sejalan dengan yang dikemukakan oleh (Daswarman, 2020) yang mengatakan kesalahan membaca akibat kurang telitinya siswa memperhatikan soal.

\section{Comprehension Error (Kesalahan Memahami Masalah)}

Berikut adalah persentase kesalahan pada comprehension error untuk setiap soal.

Tabel 6. Persentase Kesalahan Comprehension Error

\begin{tabular}{|c|c|}
\hline Nomor Soal & Persentase \\
\hline 1 & $13.04 \%$ \\
\hline 2 & $4.4 \%$ \\
\hline 3 & $0 \%$ \\
\hline
\end{tabular}




\begin{tabular}{|c|c|}
\hline 4 & $0 \%$ \\
\hline 5 & $4.4 \%$ \\
\hline
\end{tabular}

Tabel 6 memperlihatkan bahwa kesalahan comprehension error dilakukan siswa pada soal nomor 1, 2 dan 5. Pada Gambar 2 diberikan salah satu contoh kesalahan comprehension error yang dilakukan siswa AS.

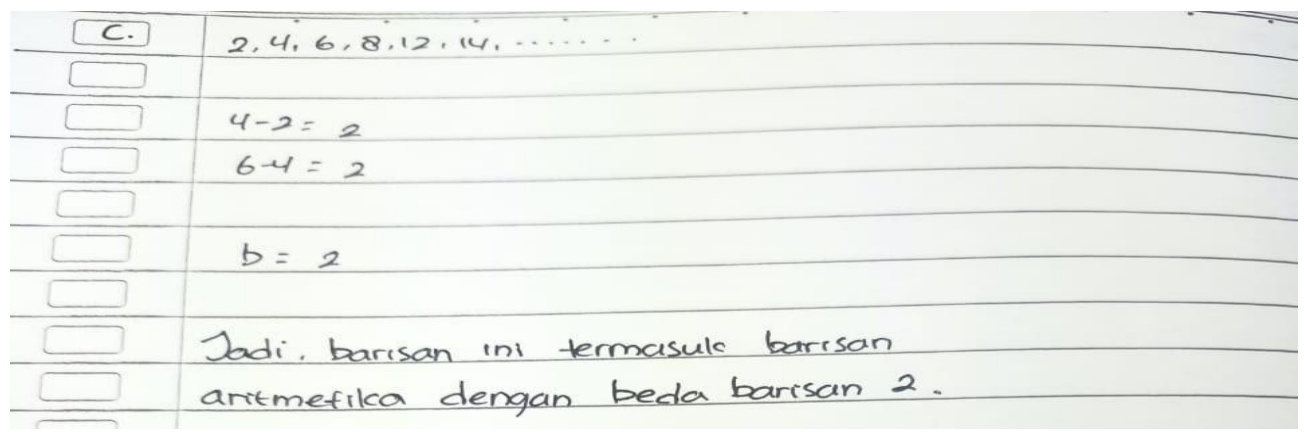

Gambar 2. Jawaban siswa soal nomor 1c

Berdasarkan Gambar 2 terlihat bahwa AS tidak memahami soal 1c. Hal ini terlihat bahwa AS langsung menyimpulkan bahwa barisan tersebut memiliki "beda" yang sama. Padahal terdapat "beda" yang tidak sama. Pada soal 1c memang benar 2, 4, 6, dan 8 memiliki selisih yang sama, akan tetapi pada suku selanjutnya yaitu 12 jelas sekali bahwa "bedanya" yakni 4 dengan suku sebelumnya. Siswa AS hanya mengamati "beda" hanya sampai tiga suku saja. Seharusnya dilamati semuanya. Hal ini terlihat bahwa siswa AS kurang memahami soal. Hal ini sejalan dengan penelitian (C. Rahmawati \& Zhanty, 2019) yang menyatakan kesalahan siswa dalam menjawab soal terjadi karena proses penafsiran informasi yang diberikan ke dalam ungkapan matematika kurang tepat. Hal ini juga sejalan dengan penelitian yang dilakukan oleh (Darmawan et al., 2018) yang mengungkapkan bahwa kesalahan memahami terjadi karena siswa tidak bisa menyebutkan apa yang diketahui dengan lengkap. Ia tidak mengidentifikasi apa yang diketahui dengan tepat sehingga menyebabkan salah penafsiran serta tidak membaca soal dengan seksama sehingga ada informasi soal yang terlewat, tidak memahami arti keseluruhan soal dengan baik sehingga tidak konsisten dalam mengidentifikasi hal yang diketahui, tidak mampu menjelaskan informasi yang terdapat dalam soal dengan tepat.

\section{Transformation Error (Kesalahan Pada Transformasi)}

Berikut adalah persentase kesalahan pada transformation error untuk setiap soal.

Tabel 7. Persentase Kesalahan Transformation Error

\begin{tabular}{|c|c|}
\hline Nomor Soal & Persentase \\
\hline 1 & $0 \%$ \\
\hline 2 & $4.4 \%$ \\
\hline 3 & $4.4 \%$ \\
\hline 4 & $13.04 \%$ \\
\hline 5 & $13.04 \%$ \\
\hline
\end{tabular}


Tabel 7 memperlihatkan bahwa kesalahan transformation error dilakukan siswa pada soal nomor 2, 3, 4 dan 5. Pada Gambar 3 diberikan salah satu contoh kesalahan transformation error yang dilakukan siswa DS.

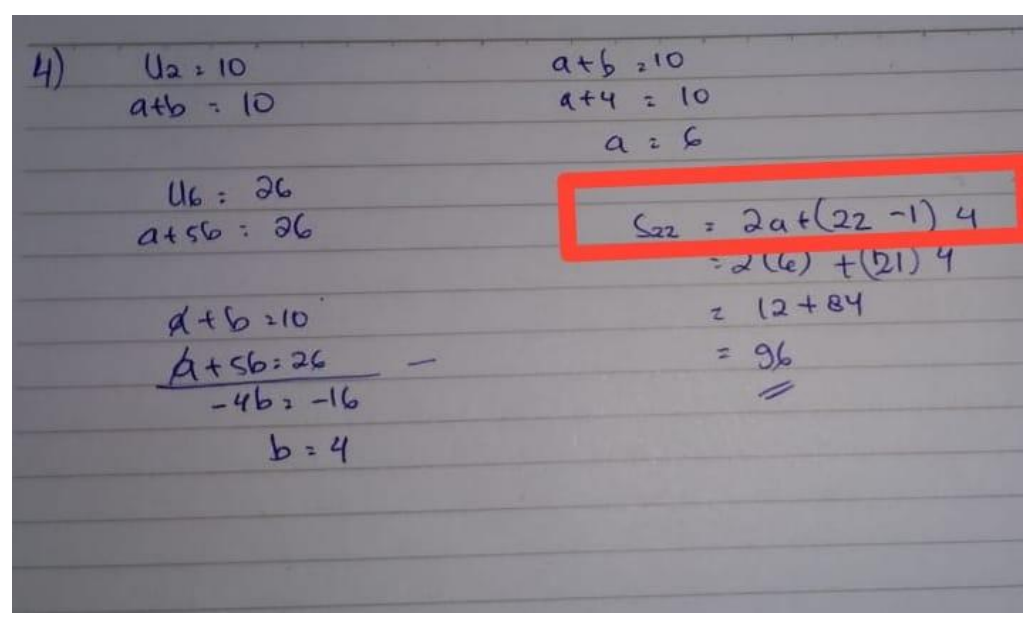

Gambar 3. Jawaban siswa soal nomor 4

Pada Gambar 3 terlihat bahwa DS mampu memahami masalah yang diberikan yaitu mencari jumlah $\left(\mathrm{S}_{22}\right)$ akan tetapi DS tidak mengetahui rumus yang akan digunakan untuk menyelesaikan soal. Terlihat pada Gambar 3 bahwa DS menulis jawaban tidak sesuai dengan rumus yang sudah dipelajari sebelumnya. Rumus jumlah suku harusnya $S_{n}=\frac{n}{2}(2 a+(n-1)$ b) akan tetapi DS membuatnya menjadi $S_{n}=(2 a+(n-1) b)$. Hal ini sesuai dengan yang dikemukakan (Magfirah et al., 2019) dimana kesalahan transformasi terjadi karena subjek tidak dapat merancang rumus yang sesuai. Hal ini juga sejalan dengan yang diungkapkan oleh (Dinnullah et al., 2019) yang mengatakan bahwa subjek penelitian yang tidak mampu mengidentifikasi metode atau strategi yang tepat dalam menyelesaikan soal yang diberikan.

\section{Process Skill Error (Kesalahan dalam Keterampilan Proses)}

Berikut adalah persentase kesalahan pada process skill error untuk setiap soal.

Tabel 8. Persentase Kesalahan Process Skill Error

\begin{tabular}{|c|c|}
\hline Nomor Soal & Persentase \\
\hline 1 & $0 \%$ \\
\hline 2 & $8.7 \%$ \\
\hline 3 & $4.4 \%$ \\
\hline 4 & $13.04 \%$ \\
\hline 5 & $17.4 \%$ \\
\hline
\end{tabular}

Tabel 8 memperlihatkan bahwa kesalahan process skill error dilakukan siswa pada soal nomor 2, 3, 4 dan 5. Pada Gambar 4 diberikan salah satu contoh kesalahan process skill error yang dilakukan siswa NN. 


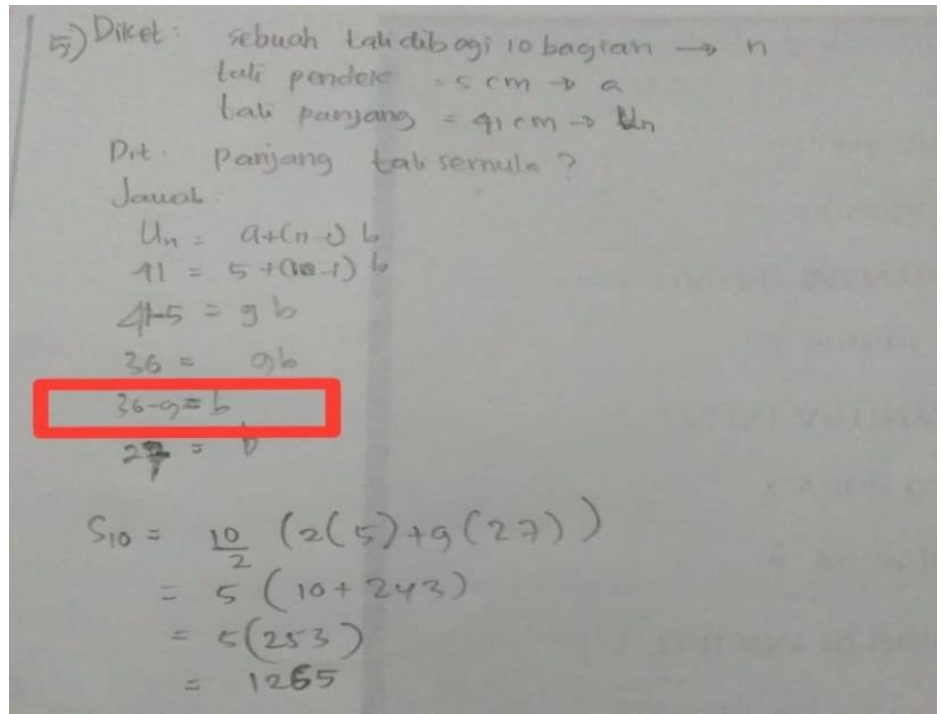

Gambar 4. Jawaban siswa soal nomor 5

Berdasarkan Gambar 4 terlihat NN mampu memilih pendekatan yang harus dilakukan untuk menemukan panjang tali semula yaitu menentukan $\mathrm{S}_{10}$. Akan tetapi saat menentukan "beda", $\mathrm{NN}$ melakukan kesalahan operasi hitung. Seharusnya NN membagi 36 dengan 9, bukan mengurangkan 36 dengan 9 sehingga beda yang didapatkan bernilai salah. Hal ini sejalan dengan (Sumadiasa, 2014) yang menyatakan bahwa ketidaktelitian siswa menyebabkan kesalahan yang terjadi pada operasi hitung. Kemudian (Rahayuningsih \& Qohar, 2014) mengatakan kesalahan proses terjadi ketika siswa tidak dapat menentukan tahapan-tahapan yang akan dilakukan dan tidak dapat melakukan operasioperasi hitung yang sesuai dan benar secara sistematis untuk mendapatkan jawaban akhir yang diinginkan. Hal ini juga sesuai dengan yang diungkapkan oleh (Haryati et al., 2016) yang menyatakan bahwa kesalahan keterampilan proses adalah kesalahan dalam menerapkan prosedur yang direncanakan, kesalahan dalam melakukan hitungan, seperti operasi kurang menjadi operasi tambah, dan kesalahan dalam melakukan operasi aljabar.

\section{Endcoding Error (kesalahan penulisan jawaban)}

Berikut adalah persentase kesalahan pada process skill error untuk setiap soal.

Tabel 9. Persentase Kesalahan Endcoding Error

\begin{tabular}{|c|c|}
\hline Nomor Soal & Persentase \\
\hline 1 & $0 \%$ \\
\hline 2 & $0 \%$ \\
\hline 3 & $0 \%$ \\
\hline 4 & $4.4 \%$ \\
\hline 5 & $4.4 \%$ \\
\hline
\end{tabular}

Tabel 9 memperlihatkan bahwa kesalahan encoding error dilakukan siswa pada soal nomor 4 dan 5. Pada Gambar 5 diberikan salah satu contoh kesalahan encoding error yang dilakukan siswa SP. 


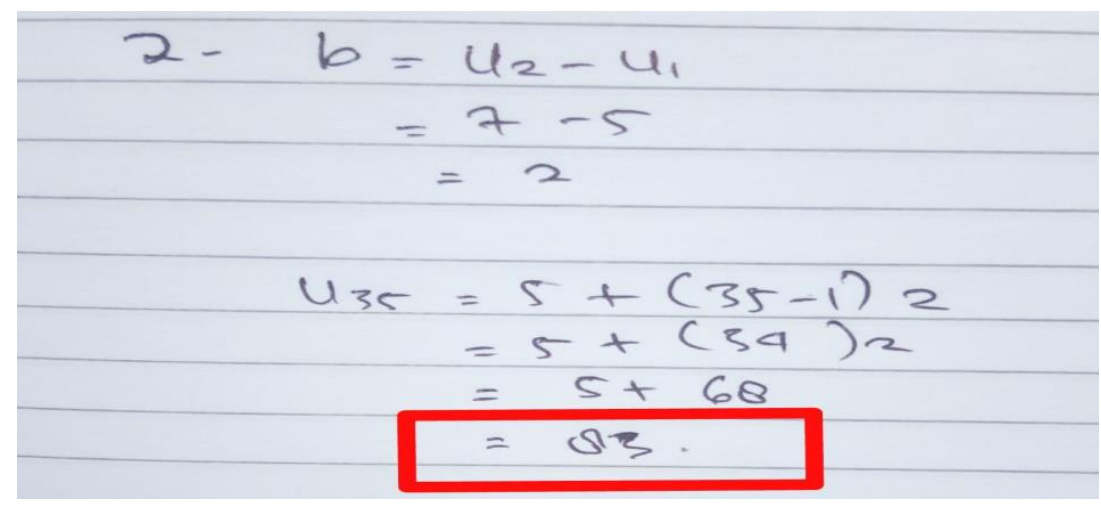

Gambar 5. Jawaban siswa soal nomor 2

Berdasarkan Gambar 5 terlihat bahwa SP mampu menyelesaikan permasalahan yang diberikan, akan tetapi SP kurang tepat dalam menuliskan hasil akhir. Hasil akhir yang dituliskan SP adalah 83 padahal jawaban yang benar adalah 73, sehingga jawaban akhir yang dituliskan tidak benar. Hal ini sejalan dengan yang dikemukakan oleh (Sudiono, 2017) bahwa dikatakan siswa melakukan kesalahan jawaban akhir jika siswa sudah dapat mengerjakan penyelesaian secara tepat tetapi tidak menuliskan kesimpulan jawaban akhir atau menyimpulkan jawaban akhir yang tidak sesuai dengan konteks soal. Lebih lanjut, (Santoso et al., 2017) sangat menyayangkan kesalahan penulisan jawaban akhir (encoding errors) karena siswa telah berhasil mencapai tahap pengolahan data tetapi gagal untuk menulis solusi akhir.

\section{KESIMPULAN}

Berdasarkan hasil penelitian yang telah dilakukan di kelas XI SMAN 1 Hulu Kuantan disimpulkan bahwa siswa masih banyak melakukan kesalahan dalam menyelesaikan soal matematika. Adapaun jenis kesalahan yang dilakukan siswa adalah: reading error, dengan persentase kesalahan sebanyak 13\%, comprehension error, dengan persentase kesalahan sebanyak $22 \%$, transformation error, dengan persentase kesalahan sebanyak 35\%, process skill error, dengan persentase kesalahan sebanyak $44 \%$, encoding error, dengan persentase kesalahan sebanyak $9 \%$.

\section{UCAPAN TERIMA KASIH}

Ucapan terimakasih disampaikan kepada semua pihak yang telah ikut berkontribusi dalam penelitian ini sehingga penelitian terlaksana dengan baik dan hasilnya bisa dituangkan dalam tulisan ini dan diinformasikan kepada pembaca.

\section{REFERENSI}

Budhi, W. S., Kartasasmita, B. G., \& Drajat, A. M. (2015). Berpikir Matematis: Matematika Untuk Sетua. Erlangga.

Darmawan, I., Kharismawati, A., Hendriana, H., \& Purwasih, R. (2018). Analisis Kesalahan Siswa SMP Berdasarkan Newman dalam Menyelesaikan Soal Kemampuan Berpikir Kritis Matematis 
pada Materi Bangun Ruang Sisi Datar. JURING (Journal for Research in Mathematics Learning), 1(1), 71-78.

Daswarman, D. (2020). Analisis Kesalahan Mahasiswa dalam Menyelesaikan Soal Matematika Ditinjau dari Prosedur Newman. JURNAL EKSAKTA PENDIDIKAN (JEP), 4(1), 73-80.

Dinnullah, R. N. I., Noni, E., \& Sumadji, S. (2019). Analisis Kesalahan Siswa pada Penyelesaian Soal Cerita Berdasarkan Tahapan Newman. Jurnal Tadris Matematika, 2(2), 175-184. https://doi.org/10.21274/jtm.2019.2.2.175-184

Ekayanti, A. (2017). Diagnosis Kesalahan Mahasiswa dalam Proses Pembuktian Berdasarkan Newmann Error Analysis. Mosharafa: Jurnal Pendidikan Matematika, 6(1), 105-116.

Fatahillah, A., Wati, Y. F., \& Susanto, S. (2017). Analisis Kesalahan Siswa dalam Menyelesaikan

Soal Cerita Matematika Berdasarkan Tahapan Newman Beserta Bentuk Scaffolding yang Diberikan. Kadikma, 8(1), 40-51.

Handayani, T., Hartatiana, H., \& Muslimahayati, M. (2020). Analisis Kesalahan Siswa dalam Menyelesaikan Soal Cerita Materi Barisan dan Deret Aritmatika. PHI: Jurnal Pendidikan Matematika, 4(2), 160-168.

Haryati, T., Suyitno, A., \& Junaedi, I. (2016). Analisis Kesalahan Siswa SMP Kelas VII dalam Menyelesaikan Soal Cerita Pemecahan Masalah Berdasarkan Prosedur Newman. Unnes Journal of Mathematics Education, 5(1).

Karnasih, I. (2015). Analisis kesalahan Newman Pada Soal Cerita Matematis (Newmans Error Analysis In Mathematical Word Problems). Jurnal Paradikma, 8(01), 37-51.

Magfirah, Maidiyah, E., \& Suryawati. (2019). Analisis Kesalahan Siswa dalam Menyelesaikan Soal Cerita Matematika Berdasarkan Prosedur Newman. Lentera Sriwijaya: Jurnal Ilmiah Pendidikan Matematika, 1(2), 1-12.

Murtikusuma, R. P. (2015). Pengembangan Perangkat Pembelajaran Matematika Model ProblemBased Learning Berbantuan Media Powerpoint Untuk Siswa Kelas XI SMK Materi Barisan dan Deret. Saintifika, 17(2).

Nur, N., Rusli, R., \& Dassa, A. (2018). Analisis Kesalahan Siswa dalam Menyelesaikan Soal Cerita Matematika pada Materi Barisan dan Deret Aritmatika. Issues in Mathematics Education (IMED), 2(1), 43-48.

Rahayuningsih, P., \& Qohar, A. (2014). Analisis Kesalahan Menyelesaikan Soal Cerita Sistem Persamaan Linear Dua Variabel (SPLDV) dan Scaffolding-nya Berdasarkan Analisis Kesalahan Newman pada Siswa Kelas VIII SMP Negeri 2 Malang. Jurnal Pendidikan Matematika Dan Sains, 2(2), 109-116.

Rahmawati, C., \& Zhanty, L. S. (2019). Analisis Kemamampuan Komunikasi Siswa Menengah Terhadap Resiliensi Matematis. JPMI (Jurnal Pembelajaran Matematika Inovatif), 2(3), 147154.

Rahmawati, D., \& Permata, L. D. (2018). Analisis Kesalahan Siswa dalam Menyelesaikan Soal Cerita 
Program Linear dengan Prosedur Newman. Jurnal Elektronik Pembelajaran Matematika, 5(2), $173-185$.

Ratnasari, Y., Rosita, C. D., \& Pramuditya, S. A. (2017). Pengaruh model pembelajaran reciprocal teaching terhadap kemampuan pemahaman dan komunikasi matematis siswa. Procediamath, 1(1).

Ristanty, E., Dinnullah, R. N. I., \& Farida, N. (2017). Penerapan Model Pembelajaran Inkuiri Terbimbing Pada Materi Segiempat dan Segitiga Terhadap Pemahaman Konsep Matematika Di Smp Islam Soerjo Alam. Pi: Mathematics Education Journal, 1(1), 8-14.

Santoso, D. A., Farid, A., \& Ulum, B. (2017). Error Analysis of Students Working about Word Problem of Linear Program With NEA Procedure. Journal of Physics: Conference Series, 855(1), 12043.

Septiahani, A., Melisari, M., \& Zanthy, L. S. (2020). Analisis Kesalahan Siswa SMK dalam Menyelesaikan Soal Materi Barisan dan Deret. Mosharafa: Jurnal Pendidikan Matematika, 9(2), 311-322.

Setiawan, Y. B., Hapizah, H., \& Hiltrimartin, C. (2018). Kesalahan Siswa dalam Menyelesaikan Soal Olimpiade SMP Konten Aljabar. Jurnal Riset Pendidikan Matematika, 5(2), 233-243.

Siregar, N. R. (2017). Persepsi Siswa Pada Pelajaran Matematika: Studi Pendahuluan Pada Siswa yang Menyenangi Game. Prosiding Temu Ilmiah Nasional X Ikatan Psikologi Perkembangan Indonesia, 1 .

Sudiono, E. (2017). Analisis Kesalahan dalam Menyelesaikan Soal Matematika Materi Persamaan Garis Lurus Berdasarkan Analisis Newman. UNION: Jurnal Pendidikan Matematik, 5(3), 295301.

Sumadiasa, I. G. (2014). Analisis Kesalahan Siswa Kelas VIII SMP Negeri 5 Dolo dalam Menyelesaikan Soal Luas Permukaan dan Volume Limas. Jurnal Elektronik Pendidikan Matematika Tadulako, 1(2).

Sunardiningsih, G. W., Hariyani, S., \& Fayeldi, T. (2019). Analisis Kesalahan Siswa Dalam Menyelesaikan Soal Matematika Berdasarkan Analisis Newman. RAINSTEK: Jurnal Terapan Sains \& Teknologi, 1(2), 41-45.

Suyitno, A., \& Suyitno, H. (2015). Learning Therapy for Students In Mathematics Communication Correctly Based-on Application of Newman Procedure (a Case of Indonesian Student). International Journal of Education and Research, 3(1), 529-538. 